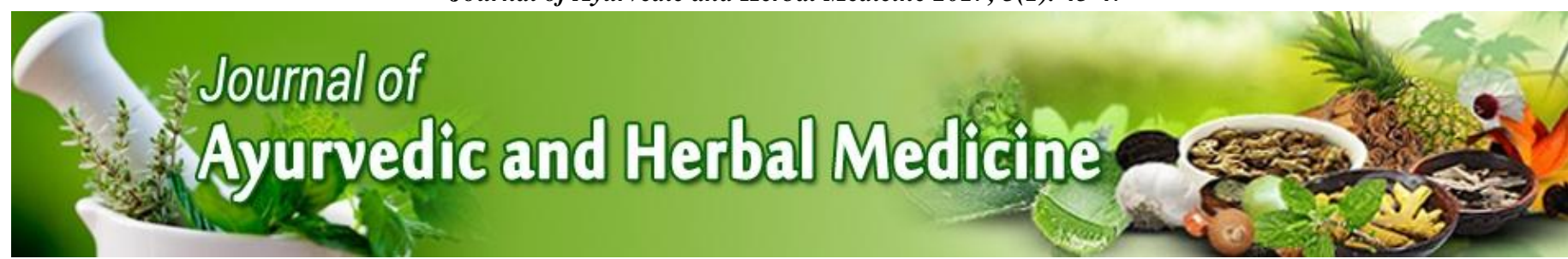

\section{Short Review}

ISSN: 2454-5023

J. Ayu. Herb. Med.

2017; 3(1): 45-47

January- March

(C) 2017, All rights reserved www.ayurvedjournal.com

Received: 20-10-2016

Accepted: 26-02-2017
*Corresponding author: Dr. Amol S Patil

HOD \& Assitant Professor, Department of Balrog, Shri Gurudeo Ayurveda College, Amravati, Maharashtra- 444902, India

\section{Traditional approaches for the management of Bala Roga: An Ayurveda perspective}

Amol S Patil ${ }^{1}$, Jagdish P Patil ${ }^{2}$, Janardhan $K^{3}$, Shardul Vikram Sing ${ }^{4}$, Ajit Dahatonde $^{5}$

1 HOD \& Assitant Professor, Department of Balrog, Shri Gurudeo Ayurveda College, Amravati, Maharashtra444902, India

2 HOD \& Assitant Professor, Department of Panchakarma, Shri Gurudeo Ayurveda College, Amravati, Maharashtra444902, India

3 Sri Adhi Siva Shadguru Shaeb Sivvarayulu Ayurveda Medical College, Guntakal, Andra Pradesh- 515807, India

4 Assitant Professor, Department of Balroga, R.K. Ayurvedic Medical College and Hospital, Azamgarh, Uttar Pradesh211009, India

5 Assitant Professor, Department of Balroga, Shri Dhanvantary Ayurveda Medical College, Mathura, Uttar Pradesh281401, India

\section{ABSTRACT}

Shishu, Bala or Kumara Avastha means childhood age described by traditional science of Indian medical system, the basic features of this age group are; lack of sexual desire, sleeping tendency and Kumara Shrira, this is an age of mental and physical development. Kaumarabhrityaka, Kaumarabhritya, Kumara Tantra or Kaumarabhritya encompasses information regarding pediatric diseases (Bala Roga). The ayurveda text Kaumarabhritya not only encompasses the information regarding pediatric diseases but also emphasized diseases of genital organs which may impart to the Bala Roga. Dhatri, Stanya, Dushti may be considered as disease causative factor in Ksheerada Avastha. The predominance and prevalence of Dosh, mala and Dushya are different in Kumara Avastha therefore especial attention require in this age to prevent chances of disease. This article summarizes role of traditional approaches of Ayurveda for the prevention, diagnosis and treatment of Bala Roga.

Keywords: Ayurveda, Bala Avastha, Bala Roga, Pediatric.

\section{INTRODUCTION}

Pathophysiology of disease mainly involves disturbances of three Doshas (Vata, Pitta, Kapha) thus doshic balance is very important for retaining good health. Kapha Dosha is predominance in Bala Avastha resulted diseases originated from disturbance of kapha dosha. Balshosha, Phakka Roga, Karshya etc., are diseases arise due to the Kapha \& Vata dosha vitiation. Ayurveda suggests diet regimen for children to maintain normal physiological functioning of body \& Doshic balance along with suggested daily life routine. In Bala Avastha physical strength is less since Dhatus are yet to be built up resulting more susceptibility for the infectious diseases; thus pediatric care needed different therapeutic approaches for the management of various disease as compared to diseases of adult age. Ayurveda suggested different modalities for the prevention, diagnosis and treatment of pediatric disease. This article emphasized preventive, diagnostic and therapeutic approaches of ayurveda for the management of Bal-Roga. ${ }^{[1-6]}$

\section{Bal-Roga: Preventive Approaches}

$>$ Stanya feeding from the birth develop immune system of Shishu; Stanya feeding is suggested by ayurveda for new born baby for Deha Pushti, Dhatu Vardhana and Bala Vardhana.

$>\quad$ Light liquid diet may be given after 6-8 months, heavy diet should be avoided which may cause constipation.

> Ayurveda also advised Phalaprashana and Annaprashana Samsakara for Bala Avastha for proper physical and mental development.

$>$ Ayurveda advocated that carbohydrates, protein, fat, minerals and vitamins enriched Ahara boost immunity of growing children; thus food stuff must encompasses all essential component of balance diet. 
> Ayurveda believe that vitiate Kappha predominate in Bala Avastha thus such food must be avoided which may vitiate Kappha Dosha.

$>$ As per medical science very cold or very hot food must be avoided in Bala Avastha to prevent any chances of PrakritiVirudha.

$>\quad$ The liquid and solid diet in Bala Avastha must be planned as per the Dohsa, Kala and Prakriti so as to avoid Virudha-Ahara which may result disease conditions.

$>$ The traditional science of Indian medical system strongly described that hygiene conditions avoid attack \& prognosis of diseases.

$>\quad$ The rules of Dinacharya \& Ritucharya help to retain normal health in Bala Avastha.

$>\quad$ The potency of drug should be fixed with great care for Bala Avastha since in this age Dosha, Dushya and Malla are less thus detoxification is not very prominent and excess amount of drug may cause harm due to the accumulation.

\section{Bal-Roga: Diagnostic Approaches}

$>\quad$ Observation of body characters and movements of suffered child along with external symptoms.

$>$ Consideration of disease associated with reproductive system of mother and Dhatri.

$>$ Graham Rogas play significant role towards the disease pathogenesis in Bala Avastha.

> Other pathologic conditions such as; Beeja Dushti, Beejabhaga, Beejabhagavayava are few genital Vyadhi which may leads pediatric disease such as; Khandoushtha, Kuchikarnika, Jatyandha, Suchimukhi and Vaarta, etc,

$>\quad$ Diet regimen of mother during pregnancy period also play significant role towards the Bal-Roga.

$>$ Nadi-Pariksha and Sharir-Pariksha should be involved in diagnostic approaches.

> Prashna Pariksha also suggests some aspect about history and prognosis of disease.

\section{Bal-Roga: Therapeutic Approaches}

$>\quad$ Panchagavya Ghrita, Smriti Sagar Ras, Yogaraj Guggulu for Murcha.

> Shringi bhasma, Shwas kuthar ras, Talisadi Churna for Kasa.

$>$ Vidangarishta, Krimikuthar ras, Vidanga Churna for Antajakrimi.

$>\quad$ Mushka Tailam, Changeri Ghrita for Guda bhramsha.

> Bhaskara Lavana Churna, Lavargodi Vati, Udarashula Lakshmivilas ras for Pratishyaya.

> Bhaskara Lavana Churna and Hingwashtak Churna for Udarashula.

$>$ Rasayana therapy as rejuvenator, to facilitate immunity and as memory enhancer.
> Herbs such as; Shankhpushpi, Guduchi, Jyotishmati, Mandookparni etc., improve Dhatus, Agni, Srotasas and Ojus.

$>$ Panchakarma therapy also play significant role in Bal Roga; since Panchakarma therapy pacify vitiated Doshas, perform detoxification and open Shrotas.

$>\quad$ Virechana control Pranavaha Sroto Vyadhi; Swasa Kasa when pitta dosha is vitiated.

$>\quad$ Nasya Karma helps in diseases which occur due to the Kapha and Vata predominance.

> Vamana eliminate Kapha Dosha by opening pranavaha srotastha. ${ }^{[4-10]}$

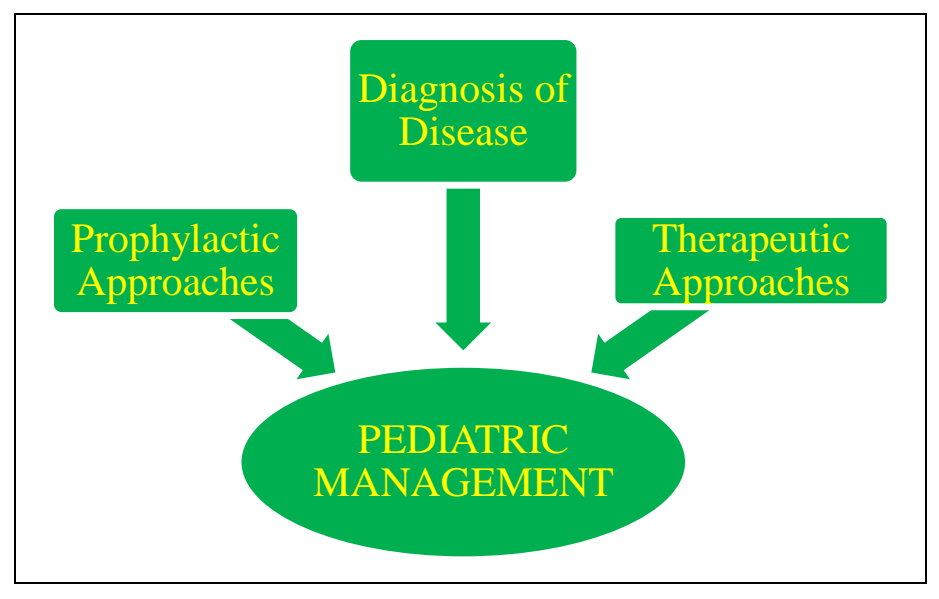

Figure 1: Approaches of Pediatric Care

\section{CONCLUSION}

Age from birth to 16 years described as Baalya as per Sushruta. Ayurveda depict different approaches for the prevention, diagnosis and management of Bal Roga. The traditional science explored use of different therapeutic approaches for the management of Bal-Roga such as; herbs, remedies, Rasayan \& Panchkarma but it is suggested that precaution is better than cure thus rules of Dinacharya \& Ritucharya need to be adopted in Bala Avastha to maintain discipline life style which help to retain normal health. Ayurveda also mentioned diagnostic approaches such as; consideration of Graham Rogas, NadiPariksha, Sharir-Pariksha and Prashna Pariksha as Nidana perspective of Bal-Roga. Ayurveda also mentioned diet regimen not only for children but also for pregnant women. This article emphasized different preventive, diagnostic and therapeutic approached of Ayurveda for the management of pediatric disease, this article may become helpful for the researches to explore novel aspect of pedantic care.

\section{REFERENCES}

1. Susruta. Susurta Samhita with Nibandhasangraha Commentary by Dalhana, editiors Acharaya YT, Acharaya Narayan R. Varanasi: Choukhambha Sanskrit Sanathan; 2003, 71.

2. Susruta. Susurta Samhita with Nibandhasangraha Commentary by Dalhana, editiors Acharaya YT, Acharaya Narayan R. Varanasi: Choukhambha Sanskrit Sanathan; 2003, 71

3. Agnivesha. Charaka Samhita with Ayurvedadipika Commentary by Chakarpanidatta, editor Acharya YT. Varanasi: Choukhambha Orientalia; 2001, 117.

4. Sulochana, Basic Concepts of Kaumarabhritya (Bala Roga), RA Journal of Applied Research, 2015; 10: 378.

5. Kumar MA, Ojha NK, Kumar A. Rationality of Swarna Prashan in Pediatric Practice. International Journal of Ayurvedic and Herbal Medicine 2013;3:1191-1200. 
6. Kumar A, Garai AK. A clinical study on Pandu Roga, iron deficiency anemia, with Trikatrayadi Lauha suspension in children. Journal of Ayurveda \& Integrative Medicine 2012;3(4):215-222.

7. Pravin M, Vedika A, Patel KS, Kori VK, Rajagopala S. An Evidence Based Review on Ayurvedic Management of Tamaka Shwasa (Bronchial Asthma), Int J Ayur Pharma Research 2015;3(2):11-18.

8. Jitesh V, Kumar SH. Current Trends in Ayurvedic Management of Cerebral Palsy in Children. Journal of Biological \& Scientific Opinion 2013;1(3):282.

9. Sharma P, Sharma B, Bohra M. Management of Cerebral Palsy due to Hypoxic-Ischemic Encephalopathy, Through Panchakarma: Case Study. World Journal of Pharmaceutical Research 2015;4(10):1705.

10. Mishra VK, Mishra N. Role of Panchakarma in Sequential Management of Pranavaha Srotastha Vyadhi in Children. World Journal of Pharmacy and Pharmaceutical Sciences 2016;5(3):527-538.

\section{HOW TO CITE THIS ARTICLE}

Patil AS, JPatil JP, Janardhan K, Sing SV, Dahatonde A. Traditional approaches for the management of Bala Roga: An Ayurveda perspective. J Ayu Herb Med 2017;3(1):45-47. 